\title{
Cardiac Status in Hepatitis B Virus and Hepatocellular Carcinoma in Egyptian Adolescents
}

\author{
Waleed Mohamed Serag ${ }^{1}$ and Eman Mohamed Elsayed ${ }^{2}$ \\ ${ }^{1}$ Chemistry Department, Faculty of Science, Suez University, Suez, Egypt \\ ${ }^{2}$ Pediatric department, Faculty of Medicine, Ain Shams University, Cairo, Egypt
}

\begin{tabular}{|c|c|}
\hline ARTICLE INFO & ABSTRACT \\
\hline $\begin{array}{l}\text { Keywords: } \\
\text { Hepatitis B virus, } \\
\text { hepatocellular carcinoma, } \\
\text { Adolescents, Troponine I , } \\
\text { Creatin Kinase MB , IL-6, } \\
\text { Anthropometry, } \\
\text { Echocardiography }\end{array}$ & $\begin{array}{l}\text { Hepatitis B virus (HBV) is the major risk factor of } \\
\text { hepatocellular carcinoma (HCC) in all age groups. There is a } \\
\text { need to find the effect of them on the cardiac status in } \\
\text { adolescence age by laboratory and physical examination for } \\
\text { assessment of different outcomes of both diseases. Cross } \\
\text { sectional study included } 15 \text { adolescents with HBV, another } 15 \\
\text { with HBV complicated by HCC and } 15 \text { healthy persons served } \\
\text { as control with age range } 12 \text { up to } 18 \text { years }(14.4 \pm 3.58) \text {. They } \\
\text { were selected for laboratory interleukin } 6 \text { (IL-6), Troponine I } \\
\text { and Creatin Kinase MB fraction (CK MB) testing and further } \\
\text { were examined at the Cardiology Unit in Pediatric department } \\
\text { of Ain Shams University hospitals for complete } \\
\text { echocardiographic and anthropometric evaluation. } \\
15 \text { patients have HCC with HBV were examined with mean age } \\
14.15 \pm 3.01 \text { years and another } 15 \text { are having HCV (14.64 } \pm 4.13 \\
\text { years). The duration of HCC was } 2.16 \pm 2.89 \text { years while the } \\
\text { exposure of HBV was } 2.27 \pm 3.35 \text { years in the HCV group. } \\
\text { Differences were found between both groups regards IL- } 6 \text { as } \\
\text { mean values were } 0.26 \mathrm{pg} / \mathrm{ml} \text { in HBV and } 0.721 \mathrm{pg} / \mathrm{ml} \text { in HCC } \\
\text { group while no differences between groups were detected } \\
\text { regards cardiac markers ; troponine I and CK MB and } \\
\text { anthropometric evaluations. In adolescent patients with HBV } \\
\text { and HBV with HCC, there is no change in the cardiac status. }\end{array}$ \\
\hline
\end{tabular}

(C) Publisher all right reserved

\section{Introduction:}

Worldwide, hepatitis B virus (HBV) is the most common among those hepatitis viruses that cause chronic infections of the liver in humans, and it represents a global public health problem, chronic hepatitis caused by HBV is the major cause of hepatocellular carcinoma (HCC) worldwide, and remains therefore a major public health problem globally1. Egypt has a marked incidence of bilharzial infection, smoking, HBV, and HCV which give us the ability to identify a high-risk group of HCC patients among the patients of chronic liver disease and cirrhosis 2 . In Egypt the incidence of HCC can increase until its peak with the year $2018^{3}$.The liver diseases affecting the heart include complications of cirrhosis such as hepatopulmonary syndrome, portopulmonary hypertension, pericardial effusion, and cirrhotic 
cardiomyopathy as well as non-cirrhotic cardiac disorders such as high-output failure caused by intrahepatic arteriovenous fistulae. Cirrhotic liver diseases are associated with abnormalities in cardiac geometry and function in adults (cirrhotic cardiomyopathy, CC) but rarely explored in cirrhotic infants or children ${ }^{4}$. The development of cardiomyopathy increases their risk of development of exercise fatigue, hepatorenal syndrome, postoperative complications, dysrhythmias، and death 5-7. In addition, several features of $\mathrm{CC}$ subside after transplant, suggesting that in the setting of cirrhosis, the heart responds to signals from the diseased liver in ways that, if prolonged, may prove detrimental to the patient ${ }^{8}$. Regards Hepatocellular carcinoma (HCC), it is the fifth most popular malignancy in the sphere, It is a prime malignancy of the liver and comes predominantly in patients with implied chronic liver disease and cirrhosis ${ }^{9}$. It's happening is rising worldwide ranging between 3\% and 9\% per year. In Egypt in last ten years the of HCC incidence has been doubled $^{10}$, and it had been notified to count for nearly $4.7 \%$ of chronic liver disease (CLD) patients, ${ }^{11}$. The evaluated happening of novel cases is about $500000-1000000$ annually, give rise to 600000 deaths globally per year ${ }^{12-14}$. Isolated Kupffer cells and LSEC have been shown to produce proinflammatory cytokines interleukin (IL)-6, and tumor necrosis factor (TNF) $\alpha$, but also IL-1 $\beta$, IL-10, and interferons 15 . The inflammatory cytokine, IL- 6 , is a cytokine with several functions that performs a master role in the reply of hepatic epithelia to inflammation 16 . Cardiac troponins (cTn) and CK MB are the preferred biomarkers for detection of myocardial cell necrosis and they are essential for the diagnosis of acute myocardial infarction (AMI) ${ }^{17}$. Therefore, the existing project was done to estimate the cardiac functions and grades of IL 6 in Egyptian adolescents with HBV and HCC.

\section{Materials and Methods}

The current project is a retrospective observational cross-sectional study of subjects who visited the Hepatology unit in Pediatric department of Ain Shams University hospitals Cairo, National Hepatology and Tropical Medicine Research Institute Cairo , Hepatology unit in Abu El-Rish children hospitals ,Cairo , National Liver Institute , Menofia and Egyptian Liver Research Institute and Hospital Publication Center , Mansoura , from attendants of outpatient clinic and from inpatients in the time between August 2014 to July 2017 under ethical committee of pediatric department, Faculty of Medicine, Ain Shams University, that is organized and operated according to the Declaration of Helsinki for human subject researcher. 15 patients have chronic HBV proved PCR without liver complications, another 15 have HCC with HBV without further complications proved by alphafetoprotein (AFP) over $800 \mathrm{ng} / \mathrm{ml}$ and 15 healthy controls were registered in this project. All studied groups were without liver complications, this due to the liver complications need prolonged time to be developed and due to the young age of the studied groups . Study Data such as age and sex were collected by using questionnaire. Cardiac assessment by Echocardiography (2D) and ECG was done at the Cardiology Unit in Pediatric department of Ain-Shams University hospitals to assess both systolic and diastolic functions, cardiac geometry and dimensions and Cardiac Index that relates the cardiac output (CO) from left ventricle in one minute to body surface area (BSA), thus 
relating heart performance to the size of the individual. The unit of measurement is liters per minute per square meter $(\mathrm{L} / \mathrm{min} / \mathrm{m} 2)$. Blood samples for the measurement of serum IL-6,Troponine I and CK MB levels were collected via venipuncture performed between 8:00 and 12:00 AM, and were detected utilizing the ELISA using a commercial kit (Ray Biotech, Inc, USA).

\section{Results}

The current study documented that 15 patients of HCC with HBV were examined with mean age $(14.15 \pm 3.01$ y) and another 15 having $\mathrm{HBV}$ $(14.64 \pm 4.13 \mathrm{y})$. The duration of HCC was $(2.16 \pm 2.89 \mathrm{y})$ while the exposure of HBV was $(2.27 \pm 3.35 \mathrm{y})$.

It was noticed that no differences were found in the cardiac status in the all groups in relation to $\mathrm{Z}$ scores of left atrial diameter, left ventricle mass, left ventricular end diastolic diameter, posterior wall thickness and interventricular septum in diastole as $(\mathrm{p}=0.424,0.075,0.120,1.000$ and 0.369 respectively) (Table1).

While comparing both echocardiographic functions between the studied groups (Tables 2,3) no significant differences were found regards both systolic functions; ejection fraction, fraction shortening, stroke volume, cardiac output, end diastolic volume and cardiac index where $(p$ value $=0.351,0.3120 .799$, $0.851,0.706$, and 0.212), and diastolic functions; $\mathrm{E} / \mathrm{A}$ ratio where $(\mathrm{P}$ value $=$ $0.604)$.

Table 4 shows significant difference between corrected QT interval in both groups as the mean QTc interval in HCC patients was $(0.46 \pm 0.04)$ that is mildly elevated and in HBV patients
$(0.42 \pm 0.02)$ that is in normal range as $\mathrm{P}$ value $=(0.039)$.

Moreover table 5 shows that no statistically significant differences were found between the 2 studied groups as regards anthropometric measurements as in comparison of the 2 groups regards $\mathrm{Z}$ scores of body weight, height and body mass index as ( $\mathrm{P}$ value $=0.602,0.892$ and 0.904$)$.

It was noticed that no differences were found in the cardiac status in the all groups in relation to cardiac biochemical markers (Tables 6,7),(Fig.1,2) .

Statistically significant difference between HCC and HBV patients was found in relation to IL- $6(\mathrm{P}<0.001)$ (Table 8)

\section{Discussion}

The adolescents patients with $\mathrm{HBsAg}$ positive and with HCC positive were rare, as HBV infection is declining due to the administration of vaccination. This agrees with Esmat G. ${ }^{18}$ who reported that according to a metaanalysis regarding viral hepatitis prevalence in Egypt, $\mathrm{HBV}$ and $\mathrm{HCV}$ were found among $25.9 \%$ and $78.5 \%$ of HCC cases. This is also in agreement with El-Zayadi ${ }^{19}$ who noticed a significant decline of HBV infection in HCC patients from $38.6 \%$ to $20.5 \%$ in their study for HCC in Egypt.

Several inflammatory cytokines included tumor necrosis factor (TNF)-a, IL-1a, IL-1b, IL-6, and IL-8, were involved in chronic liver inflammation, among IL-6 is thought the mostly important one ${ }^{20-22}$. In the current project, slightly increase grades of serum IL-6 were associated with the HBV-infected group. This outcome came in approval with findings of a polish study which showed that serum IL-6 levels are elevated in patients with 
chronic liver inflammation including alcoholic hepatitis, HBV, HCV infections, and steatohepatitis ${ }^{23}$. In this study, marked raise grades of serum IL6 were associated with the hepatocellular carcinoma infected group. IL-6 intracellular signaling includes a complex network of several pathways ${ }^{24-26}$. One study showed that IL-6 grades were raised in the patients with chronic liver disease that included cirrhosis and $\mathrm{HCC}^{27}$. However, IL-6 grades were marked elevated in HCC patients with comparison to cirrhotic patients without cancer ${ }^{28}$.

The existing results were in accordance with many other studies ${ }^{29-31}$ that showed that IL-6 grades in patients with HCC were elevated than those in LC (Liver cirrhosis), on the other hand the current results were not consistent with Ghaderi-Zefrehi $\mathbf{H}^{32}$ who displayed that IL-6 grades were normal in both chronic liver disease (CLD) and HCC patients, also were not consistent also with Metwaly HA ${ }^{33}$ who set a marked reduction in IL-6 grades in patients with HCC with the comparison to cirrhotic patients.

Cardiac troponins (cTn) are the preferred biomarkers for detection of myocardial cell necrosis and they are essential for the diagnosis of acute myocardial infarction (AMI) ${ }^{34}$. Cardiac troponins (cTn) I remain superior biomarkers for AMI diagnosis 35. Serum CK MB levels were highly significant increased in myocardial infarction compared to control group 36.

Importantly, no differences were found in the cardiac biomarkers Troponine I and $\mathrm{CK} \mathrm{MB}$ and in all echocardiographic parameters between Hepatitis B patients and HCC group including systolic and diastolic functions even most of the data remains similar to the normal healthy population, unfortunately we found no other previous studies to compare our results with, on the contrary there was a significant difference regards corrected QT interval during ECG study between the 2 groups as $p$ value $=(0.043)$, thought both values $(0.45$ and $0.42 \mathrm{Sec})$ remains in the normal range and theoretically tends to resolve with treatment, also during comparison of the anthropometric measurements no statistically significant differences were found between $\mathrm{Z}$ scores of body weight, height and body mass index. That was an expected result that needs to be confirmed by further studies even if it was in agreement with Desai $\mathbf{M S}^{4}$ as different liver conditions tend to affect the growth velocity in the adolescence stage of life.

\section{Conclusion}

We can glean from this study and these findings that in adolescents, there is no change in the cardiac status in HBV patients and HBV patients with HCC in regard to normal adolescents. Cardiac and anthropometric evaluation have failed to compare and differentiate between Hepatitis B and hepatocellular carcinoma in adolescents, though instead we can rely on biological markers that showed to be helpful as IL-6.

\section{LIST of ABBREVIATIONS}

$\begin{array}{ll}\text { HBV } & \text { Hepatitis B virus. } \\ \text { HCC } & \text { : Hepatocellular carcinoma } \\ \text { CC } & \text { : Cirrhotic cardiomyopathy } \\ \text { CLD } & \text { : Chronic liver disease } \\ \text { IL-6 } & \text { Interleukin } 6 \\ \text { CK MB : Creatin Kinase }\end{array}$

Conflicts of interests: The authors declare that they have no conflict of interest.

Funding: This research did not receive any specific grant from any funding 
agency in the public, commercial or not-for-profit sector

\section{Ethical consideration}

Written informed consents were obtained from all sharers. Each sharer has the truth to agree or reject sharing after illustrating the target. Confidentiality of collected data was secured to sharers. The survey was approved by ethical committee of pediatric department, Faculty of Medicine, Ain Shams University, that is organized and operated according to the Declaration of Helsinki for human subject researcher.

\section{Acknowledgements}

We acknowledge all physicians in the Hepatology unit and in the Cardiology Unit in Pediatric department of AinShams University hospitals and in National Hepatology and Tropical Medicine Research Institute Cairo, Hepatology unit in $\mathrm{Abu}$ El-Rish children hospitals,Cairo, National Liver Institute, Menofia and Egyptian Liver Research Institute and Hospital Publication Center, Mansoura for their help in samples collection and study.

\section{References}

1.Lavanchy D.(2005): Worldwide epidemiology of HBV infection, disease burden, and vaccine prevention. Journal of clinical virology;34(1):S1-S3.

\section{Abdel-Wahab M., El-Ghawalby} N., Mostafa M., Zakaria S., Kamel M., Abdel Khalid M., Mabrouk M. (2007): Epidemiology of hepatocellular carcinoma in Egypt Mansoura Gastrpenterology center Hepatogastroenterology;54(73): 157162.

3. Azab M., Zaki S., El-Shetey A., Abdel-Moty M., Alnoomani N., Gomaa A., Abdel-fatah S., Mohiy S., Atia F. (2011): Radiofrecquency ablation combined with percutanous ethanol injection in patients with HCC.
Arab Journal of Gastroentrology; 12: 113-118.

4.Desai MS, Zainuer S, Kennedy C, Kearney D, Goss J and Karpen SJ (2011):Cardiac structural and functional alterations in infants and children with biliary atresia, listed for liver transplantation.

Gastroenterology;141(4):1264-72.e4.

5.Henriksen JH and Møller S (2009): Cardiac and systemic haemodynamic complications of liver cirrhosis. Scandinavian Cardiovascular Journal.;43(4):218-25.

6.Rosenbaum J, Vrazas J, Lane GK and Hardikar W (2012): Cardiac cirrhosis and hepatocellular carcinoma in a 13 year old treated with doxorubicin microbead transarterial chemoembolization. Journal of paediatrics and child health;48(3):E140E3.

7.Khare J, Srivastava P, Wadhwa J and Deb P (2017): Cardiac CirrhosisAn Uncommon Manifestation of Common Disease. Oncology, Gastroenterology and Hepatology Reports;6(1).

8.Zardi EM, Zardi DM, Dobrina A and Abbate A (2017): Cirrhotic Cardiomyopathy and Liver Transplantation. Anesthesia and Perioperative Care for Organ Transplantation: Springer;p. 449-62.

9.Margini C, Vukotic R, Brodosi L, Bernardi $M$ and Andreone $P$ (2014): Bone marrow derived stem cells for the treatment of end-stage liver disease. World Journal of Gastroenterology:WJG.;20(27):9098105.

10. Anwar WA., Khaled HM., Amra HA., El-Nezami H., Loffredo CA.(2008): Changing pattern of hepatocellular carcinoma (HCC) and its risk factors in Egypt: possibilities for prevention. Mutat Res 2008;659:176184.

11.Velázquez RF, Rodriguez $M$, Navascués CA, Linares A, Pérez R, 
Sotorríos NG, et al (2003): Prospective analysis of risk factors for hepatocellular carcinoma in patients with liver cirrhosis. Hepatology;37(3):520-7.

12.Yeh CT, Chen TC, Chang ML, Hsu CW, Yeh TS, Lee WC, et al (2007): Identification of NVF virus DNA in hepatocellular carcinoma. Journal of medical virology; 79(1):92-6.

13.Blachier $M$, Leleu H, PeckRadosavljevic M, Valla D-C and Roudot-Thoraval F (2013): The burden of liver disease in Europe: a review of available epidemiological data. Journal of hepatology; 58(3):593608.

14.Pascual S, Herrera I and Irurzun

J (2016): New advances in hepatocellular carcinoma. World Journal of Hepatology;8(9):421-38.

15.Wu J, Lu M, Meng Z, Trippler M, Broering $\mathbf{R}$, Szczeponek $A$, et al (2007): Toll-like receptor-mediated control of HBV replication by nonparenchymal liver cells in mice. HEPATOLOGY ; 46: 1769-1778.

16.He G and Karin M (2011): NF- $\mathrm{BB}$ and STAT3-key players in liver inflammation and cancer. Cell research;21(1):159-68.

17.Lidija D, Kido CE (2013): Copeptin and its potential role in diagnosis and prognosis of various diseases. Biochem Med;23(2):172-92.

18.Esmat G., Elbaz T., El Akassas M.(2013) Hepatocellular Carcinoma in Egypt: an update status. WDHD May 29, 2013.

19. El-Zayadi A, Badran H, Barakat E. (2005) Hepatocellular carcinoma in Egypt: A single center study over a decade. World J. Gastroenterol.; 11(33): 5193- 5198.

20.Berasain C, Castillo J, Perugorria $M$, Latasa M, Prieto $J$ and Avila $M$ (2009): Inflammation and liver cancer. Annals of the New York Academy of Sciences.; 1155(1):206-21.
21.Sun B and Karin M (2008): NF$\kappa \mathrm{B}$ signaling, liver disease and hepatoprotective agents. Oncogene; 27(48):6228-44.

22.Zampino R, Marrone A, Restivo L, Guerrera B, Sellitto A, Rinaldi L, et al (2013): Chronic HCV infection and inflammation: Clinical impact on hepatic and extra-hepatic manifestations. World J Hepatol.; 5(10):528-40.

23. Wieckowska A., Papouchado B. G., Lopez Z. Li, R., Zein N. N., and Feldstein A.E. (2008): "Increased hepatic and circulating interleukin-6 levels in human nonalcoholic steatohepatitis, " American Journal of Gastroenterology, vol. 103, no. 6, pp. 1372-1379.

24.Hsu J-h, Shi Y, Hu L, Fisher M, Franke TF and Lichtenstein A (2002): Role of the AKT kinase in expansion of multiple myeloma clones: effects on cytokine-dependent proliferative and survival responses. Oncogene;21(9):1391.

25.Shi Y, Hsu J-h, Hu L, Gera J and Lichtenstein A (2002): Signal pathways involved in activation of p70S6K and phosphorylation of 4EBP1 following exposure of multiple myeloma tumor cells to interleukin 6.Journal of Biological Chemistry; 277(18):15712-20.

26.Bharti R, Dey $G$ and Mandal $M$ (2016): Cancer development, chemoresistance, epithelial to mesenchymal transition and stem cells: A snapshot of IL-6 mediated involvement. Cancer letters; 375(1):5161.

27.Trikha M, Corringham R, Klein $B$ and Rossi J-F (2003): Targeted antiinterleukin-6 monoclonal antibody therapy for cancer. Clinical Cancer Research; 9(13):4653-65.

28.Giannitrapani L, Soresi M, Giacalone A, Campagna ME, Marasa M, Cervello M, et al (2011): IL-6$174 \mathrm{G} / \mathrm{C}$ polymorphism and IL-6 serum 
levels in patients with liver cirrhosis and hepatocellular carcinoma. Omics: a journal of integrative biology; 15(3):183-6.

29.Hsia C-Y, Huo T-I, Chiang S-Y, Lu M-F, Sun C-L, Wu J-C, et al (2007): Evaluation of interleukin-6, interleukin-10 and human hepatocyte growth factor as tumor markers for hepatocellular carcinoma. European Journal of Surgical Oncology (EJSO);33(2):208-12.

30.Porta C, De Amici M, Quaglini S, Paglino C, Tagliani F, Boncimino A, et al (2008): Circulating interleukin-6 as a tumor marker for hepatocellular carcinoma. Annals of oncology;19(2):353-8.

31.Dondeti MF, El-Maadawy EA and Talaat RM (2016): Hepatitisrelated hepatocellular carcinoma: Insights into cytokine gene polymorphisms. World journal of gastroenterology;22(30):6800.

32.Ghaderi-Zefrehi H, GholamiFesharaki M, Sharafi H, Sadeghi F and Alavian SM (2016): The distribution of hepatitis $\mathrm{C}$ virus genotypes in Middle Eastern countries: a systematic review and meta-analysis. Hepatitis monthly; 16(9).

33.Metwaly HA, Al-Gayyar MM, Eletreby S, Ebrahim MA and ElShishtawy MM (2011): Relevance of serum levels of interleukin-6 and syndecan-1 in patients with hepatocellular carcinoma. Scientia pharmaceutica;80(1):179-88.

34.Lidija D, Kido CE (2013). Copeptin andits potential role in diagnosis andprognosis of various diseases. Biochem Med;23(2): 17292.

35. Herna' ndez DR, Marı'a GSJ, A ngel LC, Patricio PB, Puche C, Casas T, et al (2012). High-sensitivity troponin $\mathrm{T}$ and copeptin in non- ST acute coronary syndromes: implications for prognosis and role of hsTnT and copeptin in non-STEACS.
Scientific World Journal;2012, 8 pages.

36. Zeinab H. El Sayed, Hala A. Mahmoud, Layla Y. EI Shall, Fawzia A. El Sheshtawey, Manal A. Mohamed(2014). Impact of copeptin on diagnosis of acute coronary Syndrome. The Egyptian Journal of Medical Human Genetics15, 241-247. 
Table 1: Comparison between echocardiographic parameters between the studied groups

\begin{tabular}{|c|c|c|c|c|}
\hline \multirow{2}{*}{$\begin{array}{c}\text { Echocardiographic } \\
\text { parameters }\end{array}$} & \multirow{2}{*}{$\begin{array}{c}\text { HCC patients } \\
\text { with HBV }\end{array}$} & \multirow{2}{*}{ HBV patients } & \multicolumn{2}{|c|}{$\begin{array}{c}\text { Mann-Whitney } \\
\text { Test }\end{array}$} \\
\cline { 4 - 5 } & & & $\mathbf{Z}$ & P-value \\
\hline zLAD & 1.62 & -0.23 & 0.833 & 0.424 \\
\hline zLVM & 0.72 & 0.38 & 1.71 & 0.075 \\
\hline zLVEDD & 1.02 & 0.08 & 1.621 & 0.120 \\
\hline zPWD & 1.29 & 1.63 & 0.000 & 1.000 \\
\hline zIVS & 1.42 & 0.67 & 0.892 & 0.369 \\
\hline
\end{tabular}

zLAD: $Z$ score of left atrial diameter, zLVM: $Z$ score of left ventricle mass, zLVEDD: $Z$ score of left ventricular end diastolic diameter, zPWD: $Z$ score of posterior wall thickness, zIVS Z score of interventricular septum

Table 2: Comparison between systolic functions between the studied groups

\begin{tabular}{|r|c|c|c|c|}
\hline $\begin{array}{r}\text { Echocardiographic } \\
\text { Systolic Functions }\end{array}$ & HBV patients & $\begin{array}{c}\text { HCC patients with } \\
\text { HBV }\end{array}$ & \multirow{2}{*}{ T } & P \\
& Mean \pm SD & Mean \pm SD & & \\
\hline EF \% & $69 \pm 6$ & $71 \pm 8$ & 0.955 & 0.351 \\
\hline $\mathbf{F S ~ \% ~}$ & $37 \pm 5$ & $40 \pm 6$ & 1.059 & 0.312 \\
\hline $\mathbf{S V}(\mathbf{m l})$ & $42 \pm 21$ & $40 \pm 19$ & 0.211 & 0.799 \\
\hline $\mathbf{C O}(\mathbf{L} / \mathbf{m i n})$ & $4.15 \pm 2.54$ & $4.23 \pm 2.45$ & 0.298 & 0.851 \\
\hline $\mathbf{E D V}(\mathbf{m l})$ & $60 \pm 34$ & $61 \pm 29$ & 0.396 & 0.706 \\
\hline $\mathbf{C I}\left(\mathbf{L} / \mathbf{m i n} / \mathbf{m}^{2}\right)$ & $4.71 \pm 2.18$ & $5.72 \pm 2.54$ & 1.265 & 0.212 \\
\hline
\end{tabular}

t- Independent sample t-test was used in that comparison. EF: ejection fraction, FS: fraction shortening, SV: stroke volume, CO: cardiac output, EDV: end diastolic volume, CI: cardiac index 
Table 3: Comparison between diastolic functions between the studied groups

\begin{tabular}{|c|c|c|c|c|}
\hline $\begin{array}{r}\text { Echocardiographic } \\
\text { Diastolic }\end{array}$ & HBV patients & $\begin{array}{c}\text { HCC patients with } \\
\text { HBV }\end{array}$ & \multirow[t]{2}{*}{$\mathbf{T}$} & \multirow{2}{*}{$\begin{array}{c}\mathbf{P} \\
\text { value }\end{array}$} \\
\hline Functions & Mean \pm SD & Mean \pm SD & & \\
\hline E/A ratio & $1.74 \pm 1.1$ & $1.99 \pm 1.54$ & 0.488 & 0.604 \\
\hline
\end{tabular}

$\mathrm{t}$ - Independent sample t-test was used in that comparison. $\mathrm{p}$ value considered significant if $<0.05$.

Table 4: Comparison between the studied groups as regards increased QTc interval

\begin{tabular}{|l|c|c|c|c|}
\hline \multirow{2}{*}{ ECG } & HBV patients & $\begin{array}{c}\text { HCC patients with } \\
\text { HBV }\end{array}$ & \multirow{2}{*}{ T } & P value \\
\cline { 2 - 3 } & Mean \pm SD & Mean \pm SD & \\
\hline $\begin{array}{l}\text { QTc } \\
\text { interval(Sec) }\end{array}$ & $0.42 \pm 0.02$ & $0.46 \pm 0.04$ & 2.210 & 0.039 \\
\hline
\end{tabular}

$\mathrm{t}$ - Independent sample t-test was used in that comparison. $\mathrm{p}$ value considered significant if $<0.05$.

Table 5: comparison of the anthropometric measurements of the studied groups

\begin{tabular}{|c|c|c|c|c|}
\hline \multicolumn{2}{|c|}{$\begin{array}{c}\text { Anthropometric } \\
\text { measurements }\end{array}$} & HBV patients & $\begin{array}{c}\text { HCC patients } \\
\text { with HBV }\end{array}$ & $\begin{array}{c}\text { Mann- } \\
\text { Whitney Test }\end{array}$ \\
\cline { 4 - 5 } zWeight & $\begin{array}{c}\text { Median } \\
(\text { IQR) }\end{array}$ & $-0.17(1.26)$ & $-0.21(1.32)$ & 0.602 \\
\hline zHeight & $\begin{array}{c}\text { Median } \\
\text { (IQR) }\end{array}$ & $-0.137(1.83)$ & $-0.14(1.89)$ & 0.892 \\
\hline zBMI & $\begin{array}{c}\text { Median } \\
(\text { IQR) }\end{array}$ & $-0.149(1.22)$ & $-0.153(1.32)$ & 0.904 \\
\hline
\end{tabular}

IQR:interquartile range, zBMI: Z score of body mass index 
Table 6: Serum Troponine I among the studied groups

\begin{tabular}{|c|c|c|c|c||c||}
\hline $\begin{array}{c}\text { Troponine I } \\
(\mathrm{ng} / \mathrm{ml})\end{array}$ & Mean & $S D+$ & $S E+$ & t-test & $\begin{array}{c}\text { P-value of } t- \\
\text { test }\end{array}$ \\
\hline HBV & 0.13 & 0.03 & 0.01 & 0.34 & $\begin{array}{c}P>0.05 \\
\text { N.S. }\end{array}$ \\
\hline HBV + HCC & 0.13 & 0.04 & 0.01 & 0.32 & $\begin{array}{c}P>0.05 \\
\text { N.S. }\end{array}$ \\
\hline Control & 0.12 & 0.03 & 0.01 & & \\
\hline & & & & & \\
\hline
\end{tabular}

Table 7: Serum CK MB among the studied groups

\begin{tabular}{|c|c|c|c|c||c||}
\hline $\begin{array}{c}C K M B \\
(U / L)\end{array}$ & Mean & $S D+$ & $S E+$ & t-test & $\begin{array}{c}\text { P-value of } t- \\
\text { test }\end{array}$ \\
\hline$H B V$ & 0.1 & 0.02 & 0.01 & -0.57 & $\begin{array}{l}P>0.05 \\
\text { N.S. }\end{array}$ \\
\hline$H B V+H C C$ & 0.11 & 0.02 & 0.01 & 0.01 & $\begin{array}{l}P>0.05 \\
\text { N.S. }\end{array}$ \\
\hline Control & 0.11 & 0.02 & 0.01 & & \\
\hline & & & & & \\
\hline
\end{tabular}

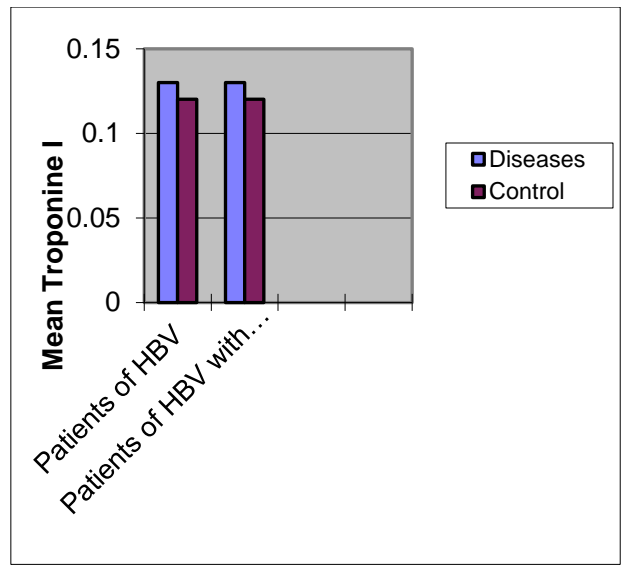

Fig.1 Serum Troponine I among the studied groups 


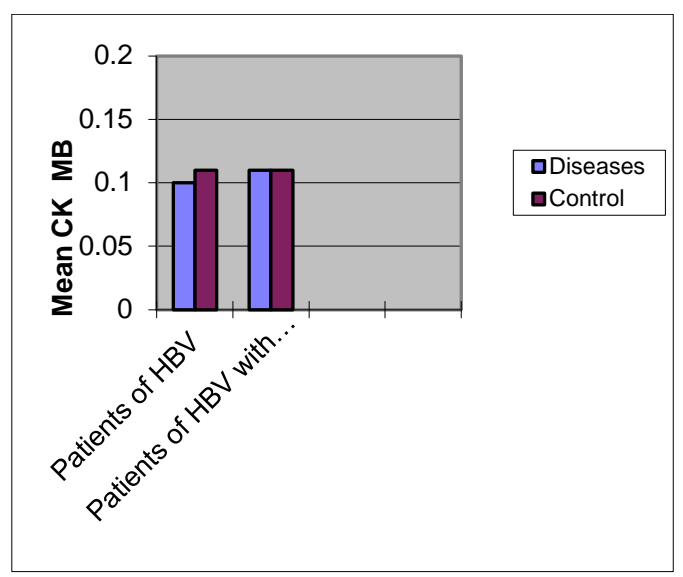

Fig.2 Serum CK MB among the studied groups

Table 8: Serum IL-6 levels among the studied groups

\begin{tabular}{|c|c|c|c|c||c||}
\hline IL-6 $(\mathrm{pg} / \mathrm{ml})$ & Mean & $S D+$ & $S E+$ & t-test & $\begin{array}{c}\text { P-value of } t- \\
\text { test }\end{array}$ \\
\hline HBV & 0.26 & 0.02 & 0.01 & 13.93 & $\begin{array}{c}P<0.001 \\
\text { H.S. }\end{array}$ \\
\hline HBV + HCC & 0.72 & 0.02 & 0.01 & 79.57 & $\begin{array}{c}P<0.001 \\
\text { H.S. }\end{array}$ \\
\hline Control & 0.15 & 0.02 & 0.01 & & \\
\hline & & & & & \\
\hline
\end{tabular}

